\author{
A.C. Iliescu 1, F.C. Corciova 1, I. Achitei 1, M. Floria 2, 3, G. Tinica 1, 2 \\ ${ }^{1}$ Institute of Cardiovascular Diseases Prof. Dr. George I.M. Georgescu, lasi, Romania \\ 2 Grigore T. Popa University of Medicine and Pharmacy, lasi, Romania \\ ${ }^{3}$ Emergency Clinical Hospital, lasi, Romania
}

\title{
Relation of body mass index to postoperative atrial fibrillation
}

The aim - to identify if body mass index is one of the predictors of postoperative atrial fibrillation in patients undergoing isolated surgical aortic valve replacement.

Materials and methods. In this single center study, we evaluated 1191 patients requiring isolated surgical aortic valve replacement between January 2000 and June 2014. The patients were followed during the early postoperative period, until their discharge.

Results. Atrial fibrillation occurred in 342 patients $(28.71 \%)$. We developed a multivariate prediction model combining six variables associated with increased risk of postoperative atrial fibrillation (advanced age, body mass index, moderate tricuspid regurgitation, prolonged ventilation, longer staying in the intensive care units and dilated left atrium $\left(\geq 35 \mathrm{ml} / \mathrm{m}^{2}\right)$ ) that has moderate predictive value $(64.7 \%)$. We also developed a tree decision model, also with moderate predictive value, including body mass index as a variable that influences arrhythmic risk in patients undergoing valvular aortic surgery.

Conclusion. The body mass index is an important variable influencing the postoperative outcome. It should be included in preoperative evaluating scores.

Key words: postoperative atrial fibrillation, body mass index, surgical aortic valve replacement.

Посилання: Iliescu A.C., Corciova F.C., Achitei I., Floria M., Tinica G. Relation of body mass index to postoperative atrial fibrillation // Кардіохірургія та інтервенційна кардіологія.- 2018.- № 4.- С. 17-22.

To cite this article: Iliescu AC, Corciova FC, Achitei I, Floria M, Tinica G. Relation of body mass index to postoperative atrial fibrillation. Cardiac Surgery and Interventional Cardiology. 2018;4(23):17-22.

$\mathbf{P}$ ostoperative atrial fibrillation (POAF) is a most common complication of cardiac surgery. Its incidence depends on the surgery type and is estimated at 40-50\% in valvular surgery cases [18]. The arrhythmia is associated with high risk of stroke, increased early and late mortality, and considerable costs. Advanced age is consistently reported to be an independent risk factor for arrhythmic complications. Increasing life expectancy caused a growing number of replaced aortic valves [2, 12, 23]. Patients undergoing aortic valve replacement have many comorbidities with cumulative arrhythmic risk; therefore, prophylactic management is needed.

Postoperative atrial fibrillation can occur anytime, mostly 2 to 4 days after surgery but possibly even after discharge, being responsible for readmissions or thromboembolic events [11, 14, 20].

The prediction models available in the literature have only moderate predictive accuracy, due to multifactorial etiology of postoperative arrhythmia.

The aim - to identify the patients at risk, in whom the prophylactic strategies should be addressed. We tried to underline the preoperative and intraoperative risk factors in patients undergoing surgical aortic valve replacement (SAVR) and to design a model that might predict the postoperative arrhythmic event, in order to apply the prophylactic medical regimens only to high risk patients.

Our specific aim was to identify if body mass index is one of the predictors of POAF in patients 
undergoing isolated surgical aortic valve replacement.

\section{Materials and methods}

In this retrospective study we performed a crosssectional analysis. We included the patients admitted between January 2000 and June 2014 in our hospital. One thousand one hundred ninety one patients out of these patients underwent cardiac aortic surgery requiring isolated SAVR. The inclusion criteria were age over 18 years, reference to our center for SAVR, signed informed consent.

The exclusion criteria were patients with history of AF; patients with other cardiac rhythms than normal sinus rhythm or patients with implanted cardiac devices, such as pacemaker or defibrillator; patients who also needed an aorto-coronary bypass or mitral valve surgery; patients who refused to be included in this study.

All patients were assessed preoperatively by means of 24 hours ECG Holter monitoring, echocardiography and coronary angiography. All data were included in an extensive database, including biologic, preoperative, intraoperative and early postoperative parameters.

The main outcome was a new-onset POAF recorded on electrocardiogram and/or telemetry. According to the definition of the 2016 Guidelines on Atrial Fibrillation of the European Society of Cardiology, POAF was defined as at least 30 seconds arrhythmia duration [10]. Patients were continuously monitored for at least 72 hours postoperatively; subsequently, they were checked twice a day or in case they were symptomatic. The patients were followed during the early postoperative period, until their discharge.

Ethics statement. The hospital Ethics Committee approved this study. Each patient was enrolled after signing informed consent.

Statistical analysis. Continuous variables are provided as mean \pm standard deviation and categorical variables as numbers and percentages. Quantitative variables were tested for normality of distribution by means of Kolmogorov - Smirnov test and were described by median and percentiles or by mean and standard deviation, whenever the case. The frequencies of nominal variables were compared with Fisher's exact test and chi-square test. Differences in the means and medians or between groups were analyzed using a t-test or a MannWhitney test, when appropriate. For the non-normal distribution of the data, we used Spearman coefficient [3].

SPSS 17.0 (SPSS inc., Chicago, IL, USA) statistical software package and Microsoft Office Excel
2013 were used for all calculations. A p value of $<0.05$ was considered statistically significant.

The logistic regression analysis was used attempting to describe a model that could predict POAF and identify patients at high-risk. We tried to use variables with the highest prediction force. The logistic regression model was derived by forward or backward approach selection, with a p-value entry of 0.02 and removed if $p<0.05$. The significance of the model was evaluated with the Wald test and the strength of association of variables with arrhythmia was estimated by calculating the $95 \%$ CIs. Discrimination of the models was assessed using the area under the curve (AUC) of the receiver operating characteristic (ROC), determined by logistic regression.

\section{Results}

Patients were divided into two groups depending on their postoperative rhythm: the POAF group (342 patients, $28.7 \%$ of the total number of patients included) and the sinus rhythm group (849 patients, $71.3 \%$ of the total number). The studied group had an average age of $64 \pm 13$ years, $67.8 \%$ being men.

Demographic data and preoperative characteristics are presented in Table 1.

Comparing the two groups, age, the body mass index, chronic kidney disease and EuroSCORE II value were variables with statistical significance. There were more hypertensive patients in the sinus rhythm group, without being statistically significant.

We described the distribution of body mass index values in Figure 1. The mean value for the entire lot of patients was $26.33 \pm 4.63 \mathrm{~kg} / \mathrm{m}^{2}$.

Multivariate analysis (Table 2) identified six variables associated with higher arrhythmic risk: advanced age, body mass index, moderate tricuspid regurgitation, prolonged ventilation, longer stay in the intensive care units and increased left atrium volume (more than $35 \mathrm{ml} / \mathrm{m}^{2}$ ).

The model including all these variables predicted POAF in $64.7 \%$ cases (Chi-square value 62.291, $\mathrm{p}=0.000)$ and had a variation of $10.5 \%$ for the independent variable. The ROC curve (Figure 2) showed that this model had a moderate discriminative power $(\mathrm{AUC}=0.65 ; \mathrm{p}=0.001 ; 95 \%$ CI 0.571 $0.771)$.

The analysis used CHAID decision tree (Figure 3), POAF being the dependent variable and age, history of arrhythmia, body mass index, left atrial volume, left ventricle ejection fraction, tricuspid regurgitation more than mild, prolonged ventilation, long stay in intensive care, diabetes and Euro SCORE the independent variables in the model. 
Maximum tree depth was four. The analysis showed that age was the most important variable, with four levels of risk for POAF: 1 ) very low risk (age under 46.8 years), 2) low risk (age between 46.8 and 57 years), 3) intermediate risk (age between 57 and 68 years) and 4) high risk (age over 68 years). For patients with low risk, the left atrial volume was the next variable with predictive value, the cut-off value

Table 1

Preoperative characteristics of patients with postoperative atrial fibrillation (POAF) compared to sinus rhythm patients

\begin{tabular}{|c|c|c|c|}
\hline Parameter & POAF group & Sinus rhythm group & P value \\
\hline Age, years (median $\pm S D)$ & $69.03 \pm 10.57$ & $64.47 \pm 14.11$ & 0.005 \\
\hline Body mass index, $\mathrm{kg} / \mathrm{m}^{2}$ (median $\left.\pm \mathrm{SD}\right)$ & $26.89 \pm 4.37$ & $26.10 \pm 4.72$ & 0.001 \\
\hline Men, \% & 63.2 & 69.8 & NS \\
\hline Smoker, \% & 49.1 & 39.1 & 0.059 \\
\hline Arterial hypertension, \% & 25.6 & 28.3 & NS \\
\hline Hyperlipidemia, mg/dl (median \pm SD) & $129.98 \pm 95.47$ & $148.84 \pm 87.50$ & 0.02 \\
\hline Diabetes mellitus, \% & 12 & 12 & NS \\
\hline EuroSCORE II (median \pm SD) & $9.00 \pm 2.87$ & $5.78 \pm 1.97$ & 0.001 \\
\hline Serum creatinine $>200 \mu \mathrm{mol} / \mathrm{l}, \%$ & 45.3 & 26.7 & 0.002 \\
\hline
\end{tabular}

Table 2

Predictors of new-onset postoperative atrial fibrillation

\begin{tabular}{|c|c|c|c|c|c|c|}
\hline Parameter & B & SE & Wald & df & Sig. & $\operatorname{Exp}(B)$ \\
\hline Body mass index & 0.029 & 0.016 & 3.179 & 1 & 0.075 & 1.030 \\
\hline Tricuspid regurgitation more than mild & 0.333 & 0.157 & 4.484 & 1 & 0.034 & 1.396 \\
\hline Prolonged ventilation & 0.168 & 0.267 & 0.396 & 1 & 0.529 & 1.183 \\
\hline Long intensive care staying (more than 3 days) & 2.070 & 0.800 & 6.698 & 1 & 0.010 & 7.925 \\
\hline Left atrium volume & 0.020 & 0.007 & 7.221 & 1 & 0.007 & 1.020 \\
\hline Age $\geq 65$ years & 0.280 & 0.07 & 17.452 & 1 & 0.000 & 1.028 \\
\hline
\end{tabular}

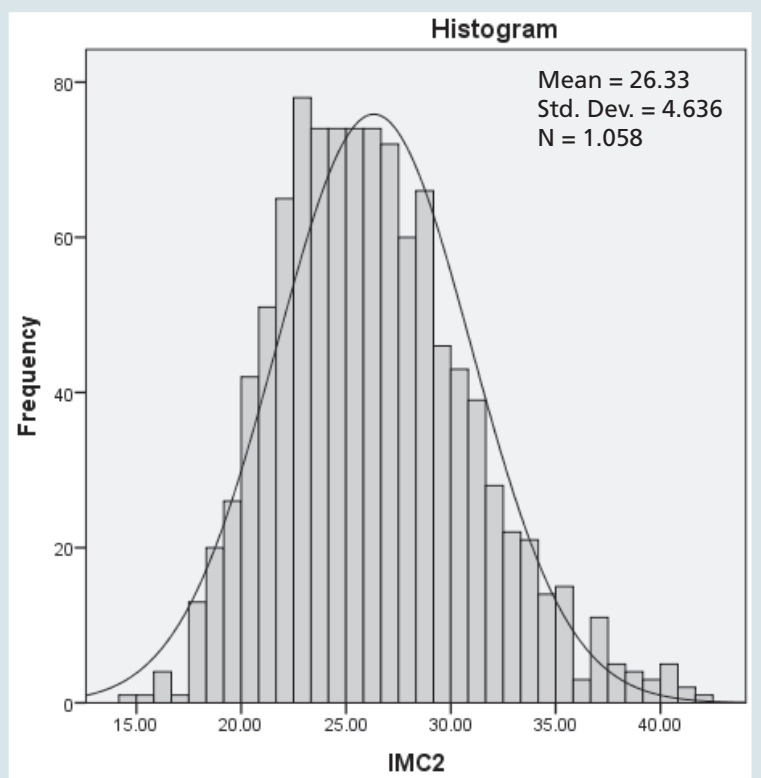

Figure 1. The distribution of the values of body mass index in the studied group

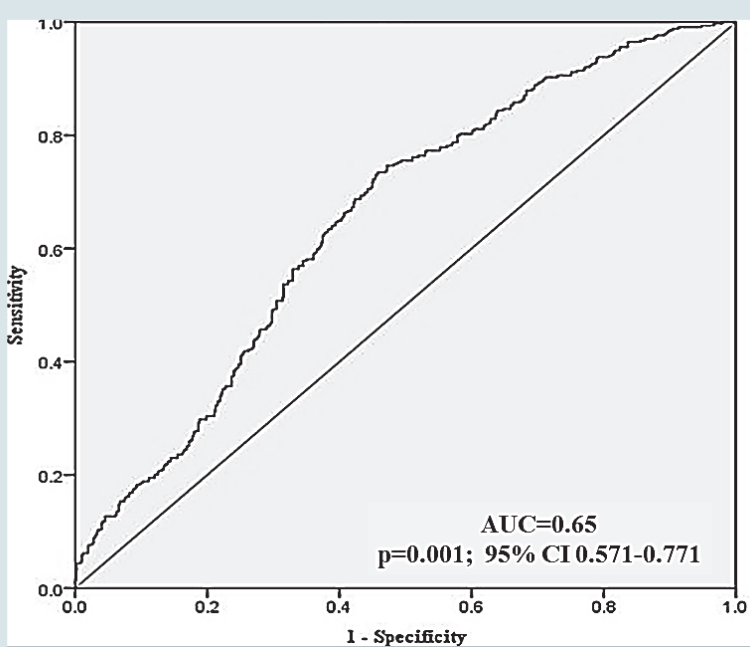

Figure 2. Receiver-operator characteristic (ROC) curve of point score as a predictor of new-onset postoperative atrial fibrillation (POAF) in patients undergoing aortic surgery 


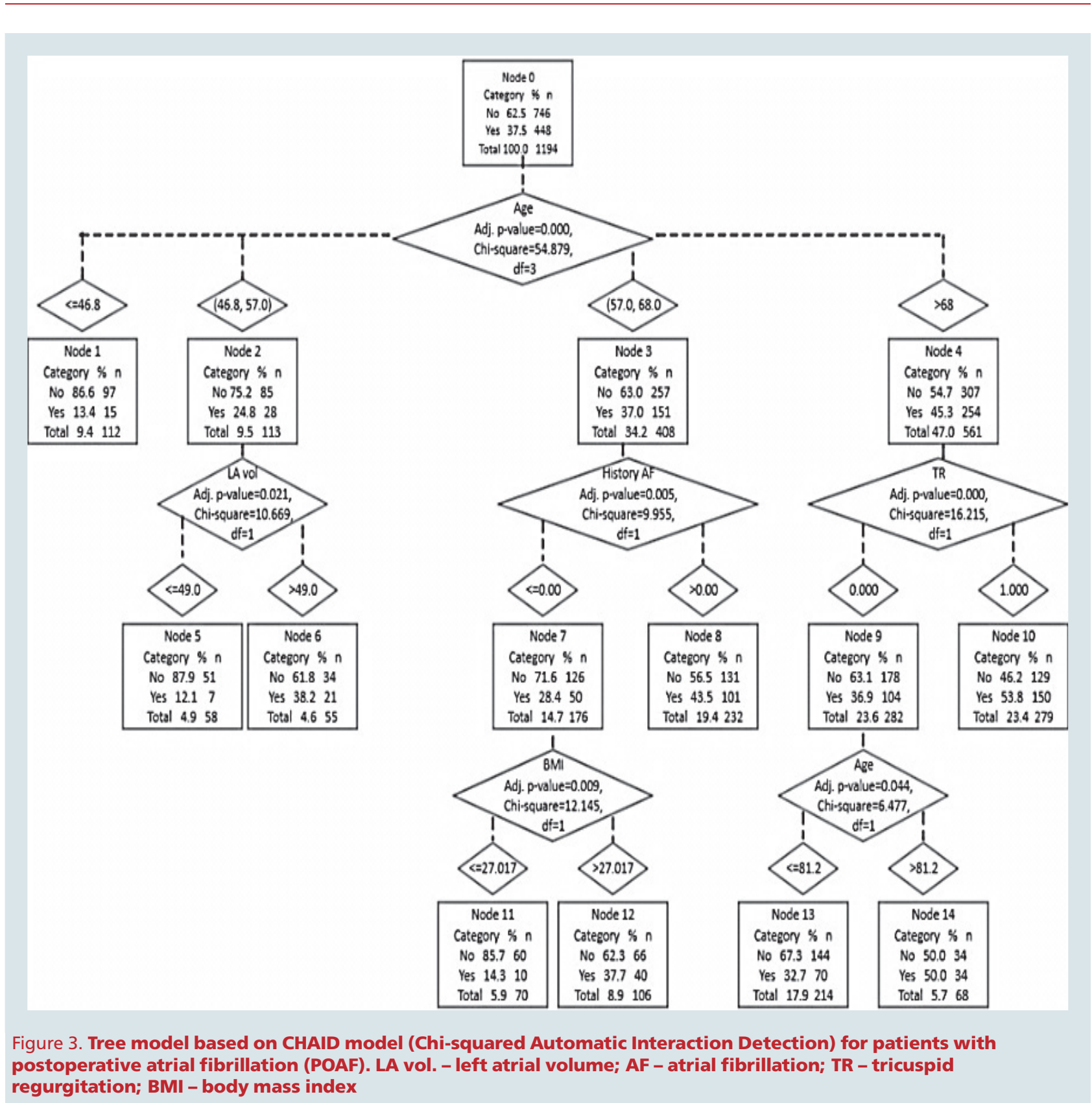

being $40 \mathrm{ml}$. In patients with intermediate risk, the history of atrial fibrillation is the next variable predicting the arrhythmia and in patients without arrhythmic history, the body mass index (with a cutoff value of $27 \mathrm{~kg} / \mathrm{m}^{2}$ ) is next in decision tree. In the high risk group, the tricuspid regurgitation at least moderate was the next predictive variable. Patients over 81 years have the highest risk.

\section{Discussions}

The overall incidence of POAF in our group was $28.71 \%$, consistent with literature reports. We used logistic regression and a tree decision analysis searching a predictive model for POAF that could be used in clinical practice. Studies reporting risk factors for POAF described different variables but there are few prediction models, mainly for patients undergoing coronary artery bypass grafting or combined surgical procedures [4, 6, 12, 13, 15]. For more reliable results, the multivariate logistic regression excluded patients with preexisting AF in which preventive management is already justified. Estimating individual risk for POAF in patients undergoing SAVR is important for applying the prophylactic strategies only in patients with high arrhythmic risk, avoiding costs and unwanted side effects in lower risk individuals [8].

K. Phan et al. [16] published meta-analysis, trying to define the relationship between obesity 
and POAF, as obesity is associated with dilated left atrium and diastolic dysfunction, triggers of POAF [1]. The analysis revealed a higher risk of POAF in obese or hypertensive patients. The obese patients are frequently hypertensive, diabetics, with obstructive sleep dyspnoea or chronic pulmonary disease, all these comorbidities being associated with increased incidence of atrial fibrillation, so it's difficult to affirm if obesity is an independent factor for POAF [7, 17, 21].

Other studies underline the necessity to adjust the results according to the body mass index and the type of surgical intervention (coronary artery bypass surgery or valvular surgery) $[9,19]$.

Our study reveals that a body mass index over $30 \mathrm{~kg} / \mathrm{m}^{2}$ is a variable with significant arrhythmic risk, consistent with other studies in the literature that also underline that obesity is associated with higher incidence of cardiovascular events and higher mortality [5]. P.A. Wolf et al. concluded in their study that obesity is a predictor of atrial fibrillation in adults due to dilated left atrium, cardiac remodelling, neuro-humoral activation and diastolic dysfunction [22].

The CHAID model (Chi-squared Automatic Interaction Detection) represents an alternative to logistic regression in developing a predictive model, according to different risk categories. The predictive value is also moderate $(64.7 \%)$. The tree decision model could be applied to heterogeneous sets of data. The tree decision described in our study identifies the body mass index as an important predictive factor for POAF in patients with intermediate risk depending on age (57 to 68 years) without previous history of atrial fibrillation.

\section{Conclusions}

Increased BMI is associated with higher risk of postoperative atrial fibrillation. The body mass index is not included in the surgical risk scores used in current clinical practice. The independent importance of increased body mass index should be evaluated in further studies.

\section{Conflict of interest: none declared.}

Authorship contributions: concept - A.C.I., M.F., G.T.; design - A.C.I., M.F., G.T.; supervision - A.C.I., M.F., G.T.; materials - A.C.I., I.A., F.C.C; data collection and/or processing - A.C.I., I.A., F.C.C.; analysis and/ or interpretation - A.C.I., F.C.C., M. F., G.T.; literature search - A.C.I., I.A.; writing - A.C.I., F.C.C.; critical review - A.C.I., M.F., G.T.

\section{References}

1. Abed HS, Samuel CS, Lau DH, et al. Obesity results in progressive atrial structural and electrical remodeling: implications for atrial fibrillation. Heart Rhythm. 2013;10:90-100.

2. Aranki SF, Shaw DP, Adams DH, Rizzo RJ, Couper GS VanderVliet $\mathrm{M}$, et al. Predictors of atrial fibrillation after coronary artery surgery. Current trends and impact on hospital resources. Circulation. 1996;94:390-7.

3. Boiculese LV, Dimitriu G, Moscalu M. Elemente de biostatistică - Analiza statistică a datelor biologice. Editura PIM. Iasi, 2007.

4. Ducceschi V, D'Andrea A, Galderisi M, et al. Risk predictors of paroxysmal atrial fibrillation following aortic valve replacement. Ital Heart J. 2001;2:507-12.

5. Engeli S, Sharma AM. The renin-angiotensin system and natriuretic peptides in obesity-associated hypertension. J Mol Med (Berl). 2001;79(1):21-9.

6. Filardo G, Hamilton C, Hamman B, et al. New-onset postoperative atrial fibrillation and long-term survival after aortic valve replacement surgery. Ann Thorac Surg. 2010;90:474-479.

7. Goudis CA, Korantzopoulos P, Ntalas IV, Kallergis EM, Ketikoglou DG. Obesity and atrial fibrillation: a comprehensive review of the pathophysiological mechanisms and links. J Cardiol. 2015;66.361-369.

8. Iliescu AC, Salaru DL, Achitei I, Grecu M, Floria M, Tinica G. Postoperative atrial fibrillation prediction following isolated surgical aortic valve replacement. Anatol J Cardiol. 2018;19(6):394-400.

9. Kaw R, Chung F, Pasupuleti V, et al. Meta-analysis of the association between obstructive sleep apnea and postoperative outcome. Br J Anaesth. 2012:109:897-906.

10. Kirchhof P, Benussi S, Kotecha D, et al. 2016 ESC Guidelines for the management of atrial fibrillation developed in collaboration with EACTS. Eur Heart J. 2016;37(38):2893-2962.

11. Lo B, Fijnheer R, Nierich AP, Bruins P, Kalkman CJ. C-reactive protein is a risk indicator for atrial fibrillation after myocardial revascularization. Ann Thorac Surg. 2005:79:1530-5.

12. Mahoney EM, Thomson TD, Veledar E, Williams J, Weintraub WS. Cost-effectiveness of targeting patients undergoing cardiac surgery for therapy with intravenous amiodarone to prevent atrial fibrillation. J Am Coll Cardiol. 2002;40:737-45.

13. Mahoney EM, Thomson TD, Veledar E, Williams J, Weintraub WS. Cost-effectiveness of targeting patients undergoing cardiac surgery for therapy with intravenous amiodarone to prevent atrial fibrillation. J Am Coll Cardiol. 2002:40:737-45.

14. Maisel WH, Rawn JD, Stevenson WG. Atrial fibrillation after cardiac surgery. Ann Intern Med. 2001;135:1061-1073.

15. Orlowska-Baranowska E, Baranowski $R$, Michalek $P$, Hoffman P, Rywik T, Rawczylska-Enlert I. Prediction of paroxysmal atrial fibrillation after aortic valve replacement in patients with aortic stenosis: Identification of potential risk factors. J Heart Valve Disease. 2003;12;136-41.

16. Phan K, Khuong JN, Xu J, Kanagaratnam A, Yan TD. Obesity and postoperative atrial fibrillation in patients undergoing cardiac surgery: Systematic review and meta-analysis. Int. J. Cardiol. 2016;15(217):49-57.

17. Russo C, Jin Z, Homma S, et al. Effect of obesity and overweight on left ventricular diastolic function: a communitybased study in an elderly cohort. J Am Coll Cardiol. 2011,57:1368-1374.

18. Shrivastava R, Smith B, Caskey D, Reddy P. Atrial fibrillation after cardiac surgery: does prophylactic therapy decrease adverse outcomes associated with atrial fibrilation. J Intensive Care Med. 2009:24:18.

19. Van Oosten EM, Hamilton A, Petsikas D, et al. Effect of preoperative obstructive sleep apnea on the frequency of atrial fibrillation after coronary artery bypass grafting. Am J Cardiol. 2014;113(6):919-923. 
20. Villareal RP, Hariharan R, Liu BC, et al. Postoperative atrial fibrillation and mortality after coronary artery bypass surgery. J Am Coll Cardiol. 2004;43(5):742-8.

21. Wanahita N. Atrial fibrillation and obesity - results of a metaanalysis. Am Heart J. 2008;155:310-315.

22. Wolf PA, Abbott RD, Kannel WB. Atrial fibrillation as an inde- pendent risk factor for stroke: the Framingham Study Stroke. 1991;22:983-988.

23. Zaman AG, Archbold RA, Helft G, Paul EA, Curzen NP Mills PG. Atrial fibrillation after coronary artery bypass surgery: a model for preoperative risk stratification. Circulation. 2000;101:1403-8.

\author{
A.C. Iliescu 1, F.C. Corciova ${ }^{1}$, I. Achitei ${ }^{1}$, M. Floria ${ }^{2}$ 3, G. Tinica ${ }^{1,2}$ \\ ${ }^{1}$ Інститут серцево-судинних захворювань імені G. Georgescu, Ясси, Румунія \\ 2 Університет медицини і фармакології імені G.T. Рора, Ясси, Румунія \\ ${ }^{3}$ Клінічна лікарня швидкої допомоги, Ясси, Румунія
}

\title{
Зв'язок індексу маси тіла з виникненням післяопераційної фібриляції передсердь
}

Мета роботи - оцінити значення індексу маси тіла як прогностичного фактора щодо виникнення післяопераційної фібриляції передсердь у пацієнтів, яким виконують ізольовану операцію заміни аортального клапана.

Матеріали і методи. В одноцентровому дослідженні проаналізовано дані 1191 пацієнта, госпіталізованого для виконання ізольованої операції заміни аортального клапана в період із січня 2000 р. до червня 2014 р. Пацієнтів спостерігали в ранній післяопераційний період, до їх виписування зі стаціонару.

Результати. Фібриляція передсердь виникла у 342 (28,71 \%) хворих. Розроблено багатоваріантну модель прогнозування, яка поєднує шість змінних, пов'язаних з підвищеним ризиком виникнення післяопераційної фібриляції передсердь (похилий вік, індекс маси тіла, помірна регургітація на трикуспідальному клапані, тривала вентиляція, тривале перебування у відділенні інтенсивної терапії та збільшення лівого передсердя (індекс об'єму лівого передсердя $\geq 35$ мл/м²). Ця модель має помірне прогностичне значення (64,7 \%). Встановлено помірну прогностичну цінність моделі, до якої входить індекс маси тіла як змінна, що впливає на ризик виникнення аритмії в пацієнтів, котрим виконують операцію на аортальному клапані.

Висновок. Індекс маси тіла - це важливий фактор, який впливає на перебіг післяопераційного періоду. Отже, цей показник повинен враховуватися при оцінюванні прогнозу наслідків хірургічного втручання.

Ключові слова: післяопераційна фібриляція передсердь, індекс маси тіла, операція заміни аортального клапана.

\author{
A.C. Iliescu ${ }^{1}$, F.C. Corciova ${ }^{1}$, I. Achitei ${ }^{1}$, M. Floria ${ }^{2,3}$, G. Tinica ${ }^{1,2}$ \\ ${ }^{1}$ Институт сердечно-сосудистых заболеваний имени G. Georgescu, Яссы, Румыния \\ 2 Университет медицины и фармакологии имени G.T. Рора, Яссы, Румыния \\ ${ }^{3}$ Клиническая больница скорой помощи, Яссы, Румыния

\section{Связь индекса массы тела с возникновением} \\ послеоперационной фибрилляции предсердий
}

Цель работы - оценить значение индекса массы тела как прогностического фактора для возникновения послеоперационной фибрилляции предсердий у пациентов, которым выполняют изолированную операцию замены аортального клапана.

Материалы и методы. В одноцентровом исследовании проанализированы данные 1191 пациента, госпитализированного для выполнения изолированной операции замены аортального клапана в период с января 2000 до июня 2014 года. Пациентов наблюдали в ранний послеоперационный период, до их выписки из стационара.

Результаты. Фибрилляция предсердий возникла у 342 (28,71\%) больных. Разработана многовариантная модель прогнозирования, которая сочетает шесть переменных, связанных с повышенным риском возникновения послеоперационной фибрилляции предсердий (пожилой возраст, индекс массы тела, умеренная регургитация на трикуспидальном клапане, длительная вентиляция, длительное пребывание в отделении интенсивной терапии и увеличение левого предсердия (индекс объема левого предсердия $\geq 35$ мл/м²). Эта модель имеет умеренное прогностическое значение $(64,7$ \%). Установлена умеренная прогностическая ценность модели, в которую входит индекс массы тела как переменная, влияющая на риск возникновения аритмии у пациентов, перенесших операцию на аортальном клапане.

Выводы. Индекс массы тела является важным фактором, влияющим на течение послеоперационного периода. Следовательно, этот показатель должен учитываться при оценке прогноза результатов хирургического вмешательства.

Ключевые слова: послеоперационная фибрилляция предсердий, индекс массы тела, операция замены аортального клапана. 